\title{
BRITISH SOCIETY OF
}

\section{ANIMAL PRODUCTION}

\section{Reports}

Third Meeting, 2Ist February, I945

General Topic :

MEAT

\author{
Fourth Meeting, I7th July, I945 \\ General Topic : \\ BRITISH PIG PRODUCTION
}

PUBLISHED BY THE SOCIETY

Price 2s. 6d., post free to Non-Members on application to the Secretary-Treasurer 


\section{BRITISH SOCIETY OF ANIMAL PRODUCTION}

\section{EXEGUTIVE COMMITTEE, 1945}

President : Professor R. G. White.

Vice-President: Mr. J. A. Scott Watson.

Mr. E. C. J. Allday.

Mr. T. L. Bywater.

Mr. J. R. CURrie.

DR. A. B. FoWler.

Mr. M. GRIFFITH.

Dr. J. Hammond.

Mr. Aleg Hobson.

Professor W. G. Miller.

Mr. A. R. Wannop.

Secretary-Treasurer : DR. J. E. Nichols, Imperial Bureau of Animal

Breeding and Genetics, King's Buildings, West Mains Road, Edinburgh, 9. 
The Third Meeting was held on 2 ist February, i 945 AT THE

London School of Hygiene and Tropical Medicine

The Fourth Meeting was held on i ith July, 1945 IN THE

Zoology Lecture Theatre, University of Reading 